\title{
APPLICATIONS OF ISSR MARKERS IN STUDIES OF GENETIC DIVERSITY OF Pityrocarpa moniliformis ${ }^{1}$
}

\author{
FRANCIVAL CARDOSO FELIX ${ }^{2}$, KYVIA PONTES TEIXEIRA DAS CHAGAS ${ }^{2}$, CIBELE DOS SANTOS FERRARI ${ }^{2}$, \\ FÁBIO DE ALMEIDA VIEIRA ${ }^{2}$, MAURO VASCONCELOS PACHECO ${ }^{2 *}$
}

\begin{abstract}
Pityrocarpa moniliformis (Benth.) Luckow \& R. W. Jobson (Fabaceae) is a native brazilian species with high potential for economic development programs in semiarid regions, mainly related to the production of honey, animal food and firewood. Thus, the objective of this work was to select Inter-Simple Sequence Repeat (ISSR) molecular markers for genetic diversity studies, as well as to test the efficiency of this approach in quantifying the genetic diversity of a natural $P$. moniliformis population. For this, 28 ISSR molecular markers were tested, evaluating the total number of loci, polymorphism rate and the Polymorphism Information Content (PIC) for the selected primers, the "Marker Index", and the "Resolving Power". Genetic diversity parameters (Nei genetic distance and Shannon index) were evaluated for 30 individuals located in Macaíba, Rio Grande do Norte State, Brazil. Seven primers were selected, which provided 74 loci, with $82 \%$ being polymorphic, while the PIC value was 0.344 . The Nei genetic distance was 0.244 , and the Shannon index was 0.374. Therefore, ISSR molecular markers (UBC 827, 840, 844, 857, 859, 860 and 873) are considered efficient in studying the genetic diversity of populations for the selection of matrices and germplasm banks, and may contribute to the conservation and genetic improvement of $P$. moniliformis populations.
\end{abstract}

Keywords: Semiarid. Conservation. Dry forests. Inter-Simple Sequence Repeat. Molecular markers.

\section{APLICAÇÕES DE MARCADORES ISSR EM ESTUDOS DE DIVERSIDADE GENÉTICA DE Pityrocarpa moniliformis}

\begin{abstract}
RESUMO - Pityrocarpa moniliformis (Benth.) Luckow \& R. W. Jobson (Fabaceae) é uma espécie nativa do Brasil com alto potencial em programas de desenvolvimento econômico em regiões semiáridas, principalmente relacionado à produção de mel, alimentação animal e madeira para lenha. Assim, o objetivo deste trabalho foi selecionar marcadores moleculares Inter-Simple Sequence Repeat (ISSR) para estudos de diversidade genética, bem como testar a eficiência desta abordagem na quantificação da diversidade genética de uma população natural de $P$. moniliformis. Para isso, testaram-se 28 marcadores moleculares ISSR, avaliando-se o número total de locos, taxa de polimorfismo e o valor de conteúdo de informação polimórfica (PIC) para os iniciadores selecionados, bem como o índice de marcador e o poder de resolução. Os parâmetros de diversidade genética (distância genética de Nei e índice de Shannon) foram avaliados em 30 indivíduos localizados em Macaíba, Rio Grande do Norte, Brasil. Foram selecionados sete iniciadores que forneceram 74 locos, sendo $82 \%$ polimórficos, enquanto o valor de PIC foi de 0,344. A distância genética de Nei foi de 0,244 e o índice de Shannon, de 0,374. Portanto, marcadores moleculares ISSR (UBC 827, 840, 844, 857, 859, 860 e 873) são considerados eficientes nos estudos de diversidade genética de populações, seleção de matrizes e bancos de germoplasma, e podem contribuir para a conservação e o melhoramento genético em populações de $P$. moniliformis.
\end{abstract}

Palavras-chave: Semiárido. Conservação. Florestas secas. Inter Simple Sequence Repeat. Marcadores moleculares.

\footnotetext{
${ }^{*}$ Corresponding author

${ }^{1}$ Received for publication in $04 / 01 / 2020$; accepted in $08 / 24 / 2020$.

Paper extracted from the master dissertation of first author.

${ }^{2}$ Specialized Academic Unit in Agricultural Sciences, Universidade Federal do Rio Grande do Norte, Macaíba, RN, Brazil; franciva1007@gmail.com - ORCID: 0000-0002-6518-5697, kyviapontes@gmail.com - ORCID: 0000-0003-1361-3204, cibeferrari@hotmail.com - ORCID: 0000-0003-2940-0190, vieirafa@gmail.com - ORCID: 0000-0003-3347-255X, pacheco.sementes@gmail.com - ORCID: 0000-0002-0447-9800.
} 


\section{INTRODUCTION}

Pityrocarpa moniliformis (Benth.) Luckow \& R. W. Jobson (Fabaceae) is a tree species that predominantly occurs in dry forests in Northeast Brazil and is popularly known as catanduva. These native species have social, ecological and economic potential, mainly due to their role in supplying wood for firewood, forage for animal feed, honey production and the recovery of degraded areas (AZERÊDO; PAULA; VALERI, 2011).

The wood from $P$. moniliformis presents excellent mechanical properties, as it demonstrates high density in relation to other currently commercialized species (NASCIMENTO et al., 2015). It has recently been found that its leaves, bark and fruits present high level of antioxidants, which can be used as phytotherapy in fighting against cancer cells (ALVES et al., 2014), and its seeds have secondary metabolites with larvicidal properties against Aedes aegypti L. vectors, which transmit viral diseases (FARIAS et al., 2010).

There is a great wealth of honey producing plants in the natural areas of this species; $P$. moniliformis is one of seven in the genus that is frequented by bees and is considered to be a honey plant (ALVES et al., 2014). Thus, it is one of the tree species that contributes most to the honey supply, both in terms of quality and quantity, these being requirements that are important for the consumer market (JESUS et al., 2015).

Therefore, knowledge regarding the genetic variability of natural populations contributes to the development and incorporation of the species into productive systems (COSTA et al., 2011). Additionally, these studies can support conservation and forest improvement programs, aiding the socioeconomic development of farmers and enabling in situ conservation in order to prevent a decline in the natural occurrence of the species (SIMON, 2010).

Molecular markers are widely used to characterize genetic variability (KOUR et al., 2014) among individuals and populations (COSTA et al., 2011), in addition to being used in conservation and forest improvement programs (LORENZONI et al., 2014). Among such markers, we focus on the ISSR (Inter-Simple Sequence Repeat), which are dominant markers used in genetic diversity studies, with low development cost, a high polymorphism rate and high reproducibility (CHEN et al., 2017). In addition, ISSR molecular markers can be used for diverse plant species without the need for genetic sequencing and can be indicated for studies of diversity and genetic mapping of populations.

In the north-eastern semiarid region, recent studies using ISSR molecular markers have been conducted on Copernicia prunifera (Mill) H. E. Moore (FAJARDO et al., 2018), Croton linearifolius Mull. Arg. (SILVA et al., 2018), Elaeis guineensis Jacquin (CHAGAS et al., 2019), Erythrina velutina Willd. (GONÇALVES et al., 2014), Hancornia speciosa Gomes (COSTA et al., 2015), Mimosa caesalpiniifolia Benth. (ARAÚJO et al., 2016), Myracrodruon urundeuva Allemão (LOPES; COSTA; ARRIEL, 2020), Stylosanthes scabra J. Vogel (COSTA et al., 2018), Syagrus cearensis Noblick (NEVES et al., 2019) and Ziziphus joazeiro Mart. (DUARTE; NOGUEIRA; VIEIRA, 2018), aiming to demonstrate their efficiency in accessing genetic diversity in different populations.

Thus, the objective of this study was to select ISSR molecular markers to be used in genetic diversity studies, as well as to test the efficiency of this approach in quantifying the genetic diversity of a natural $P$. moniliformis population.

\section{MATERIAL AND METHODS}

\section{Collection of leaf material and DNA extraction}

Leaf samples were collected from 30 naturally occurring $P$. moniliformis individuals, with the distance between them being two and a half times their height, located near the Forest Experimentation Area ( $5^{\circ} 54^{\prime} 01^{\prime \prime} \mathrm{S}$ and $35^{\circ} 21^{\prime} 28^{\prime \prime}$ $\mathrm{W}$, radius of $1000 \mathrm{~m}$ ) of the Unidade Acadêmica Especializada em Ciências Agrárias (Figure 1), Universidade Federal do Rio Grande do Norte, Macaíba City, Rio Grande do Norte State, Brazil.

The samples were then transferred to tubes containing $2 \% \quad$ CTAB $2 \mathrm{X}$ detergent buffer (cetyltrimethylammonium bromide) and kept in a freezer at $-20{ }^{\circ} \mathrm{C}$. The DNA was extracted using the protocol proposed by Doyle and Doyle (1987), [100 $\mathrm{mM}$ Tris $\mathrm{pH} 8.0 ; 1.4 \mathrm{M} \mathrm{NaCl} ; 20$ mM EDTA $\mathrm{pH} 8.0$; $2 \%\left({\mathrm{w} . \mathrm{v}^{-1}}^{-1}\right.$ CTAB; $1 \%\left(\mathrm{w} . \mathrm{v}^{-1}\right)$ PVP-40 and $0.2 \%$ $\left(\mathrm{v} . \mathrm{v}^{-1}\right)$ of $\beta$-mercaptoethanol preheated at $60{ }^{\circ} \mathrm{C}$ in a water bath]. The samples were subsequently quantified in a spectrophotometer. 

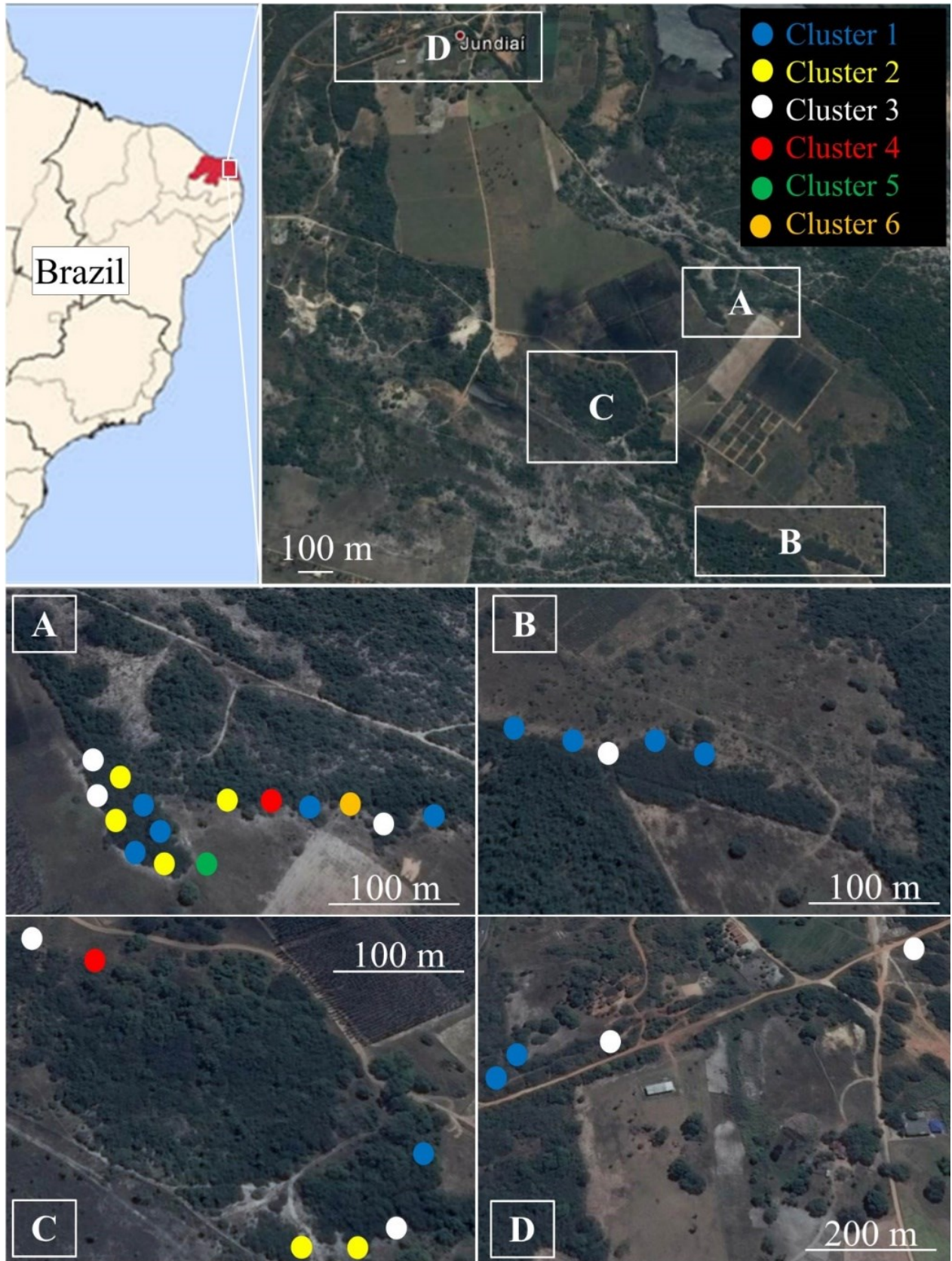

Figure 1. Spatial distribution of the 30 P. moniliformis individuals in six groups (Nei genetic identity cut-off point at 0.76 ) in a population of the Unidade Acadêmica Especializada em Ciências Agrárias, Macaíba City/Rio Grande do Norte State, Brazil (Google Earth Pro, 2018).

\section{DNA amplification with ISSR markers}

Twenty-eight (28) ISSR molecular primers (University of British Columbia - UBC) (Table 1) were tested, with the selection criteria consisting of choosing the primers that presented the best amplification standards and loci resolution quality.

Amplification of the PCR (Polymerase Chain Reaction) for both primer selection and genetic diversity assessment contained $12 \mu \mathrm{L}$ final volume per sample, $2.0 \mu \mathrm{L}$ DNA (50 ng. $\mu \mathrm{L}^{-1}$ ) and $10.0 \mu \mathrm{L}$ of the reaction product combination [2.0 $\mu \mathrm{L}$ ISSR Primer $0.33 \mu \mathrm{M} ; 1.2 \mu \mathrm{L}$ of PCR buffer (IC
Phoneutria ${ }^{\circledR}$ Buffer); $3.0 \mu \mathrm{L}$ of BSA $0.25 \mathrm{mg} \cdot \mathrm{mL}^{-1}$; $0.48 \mu \mathrm{L} \mathrm{MgCl}_{2} 2.0 \mathrm{mM} ; 1.2 \mu \mathrm{L}$ dNTPs $2.0 \mathrm{mM} ; 0.2$ $\mu \mathrm{L}$ of Taq DNA polymerase $0.5 \mathrm{U} . \mu \mathrm{L}^{-1}$ and $2.0 \mu \mathrm{L}$ of ultrapure water].

Amplification DNA reactions were performed in a thermocycler over a period of $1 \mathrm{~h} 40 \mathrm{~min}$. The following steps were used: initial denaturation at $94^{\circ}$ $\mathrm{C}$ for $2 \mathrm{~min}$, followed by 37 cycles of $15 \mathrm{~s}$ at $94{ }^{\circ} \mathrm{C}$ for denaturation, $30 \mathrm{sec}$ at $47^{\circ} \mathrm{C}$ for annealing the ISSR primers and $1 \mathrm{~min}$ at $72{ }^{\circ} \mathrm{C}$ for extension, with final extension at $72{ }^{\circ} \mathrm{C}$ for $7 \mathrm{~min}$ and subsequent cooling at $4{ }^{\circ} \mathrm{C}$. 
Table 1. ISSR primers with their respective nucleotide sequences and total number of amplified loci for P. moniliformis.

\begin{tabular}{|c|c|c|}
\hline ISSR Primer & $\begin{array}{c}\text { Sequence of } \\
\text { nucleotides }\left(5^{\prime}-3^{\prime}\right)\end{array}$ & Total number of loci \\
\hline UBC 807 & AGAGAGAGAGAGAGAGT & 3 \\
\hline UBC 808 & AGAGAGAGAGAGAGAGC & 6 \\
\hline UBC 809 & AGAGAGAGAGAGAGAGG & 2 \\
\hline UBC 810 & GAGAGAGAGAGAGAGAT & 6 \\
\hline UBC 813 & СТСТСТСТСТСТСТСТТ & 7 \\
\hline UBC 818 & CACACACACACACACAG & 7 \\
\hline UBC 821 & GTGTGTGTGTGTGTGTT & 4 \\
\hline UBC 822 & ТСТСТСТСТСТСТСТСА & 4 \\
\hline UBC 824 & TCТСТСТСТСТСТСТСG & 6 \\
\hline UBC 825 & ACACACACACACACACT & 5 \\
\hline UBC 826 & ACACACACACACACACC & 9 \\
\hline UBC 827 & ACACACACACACACACG & 10 \\
\hline UBC 829 & TGTGTGTGTGTGTGTGC & 7 \\
\hline UBC 830 & TGTGTGTGTGTGTGTGG & 5 \\
\hline UBC 840 & GAGAGAGAGAGAGAGAYT & 7 \\
\hline UBC 841 & GAGAGAGAGAGAGAGAYC & 7 \\
\hline UBC 842 & GAGAGAGAGAGAGAGAYG & 6 \\
\hline UBC 843 & CTCTCTCTCTCTCTCTRA & 5 \\
\hline UBC 844 & CTCTCTCTCTCTCTCTRC & 6 \\
\hline UBC 851 & GTGTGTGTGTGTGTG TYG & 7 \\
\hline UBC 857 & ACACACACACACACACYG & 9 \\
\hline UBC 859 & TGTGTGTGTGTGTGTGRC & 10 \\
\hline UBC 860 & TGTGTGTGTGTGTGTGRA & 7 \\
\hline UBC 862 & AGCAGCAGCAGCAGCAGC & 3 \\
\hline UBC 873 & GACAGACAGACAGACA & 7 \\
\hline UBC 880 & GGAGAGGAGAGGAGA & 8 \\
\hline UBC 881 & GGGTGGGGTGGGGTG & 6 \\
\hline UBC 898 & CACACACACACARY & 4 \\
\hline Average & & 6 \\
\hline
\end{tabular}

\section{Electrophoresis}

After the amplification reaction, $5 \mu \mathrm{L}$ of the PCR product was stained with $4 \mu \mathrm{L}$ of bromophenol blue and GelRed ${ }^{\mathrm{TM}}$, and placed in an agarose gel (1.5 $\left.\mathrm{W} . \mathrm{v}^{-1}\right)$ submitted to electrophoresis on a horizontal system. In this step, a negative PCR control sample was employed without DNA. A $1 \mathrm{~KB}$ molecular weight marker $\left(\right.$ Ladder Kasvi ${ }^{\circledR}$ ) was used. The agarose gel was then immersed in $1 \mathrm{X}$ TAE buffer (Tris-acetate-EDTA) and maintained at $100 \mathrm{~V}$ for $2 \mathrm{~h}$ 30 min. The electrophoresis product was photographed under ultraviolet light in an E-Box ${ }^{\mathrm{TM}}$ VX2.

\section{Data analysis}

The total number of loci, total number of polymorphic loci, polymorphism rate and Polymorphism Information Content (PIC) value were evaluated according to the equation proposed by Anderson et al. (1993):

$$
\mathrm{PIC}_{i}=1-\sum_{J=1}^{n} P_{i j}^{2}
$$

in which $\mathrm{P}_{i j}$ is the frequency of the allele " $j$ " in the primer " $i$ ".

The Marker Index (MI) was calculated as described by Varshney et al. (2007), the Resolving Power (RP) calculated according to Prevost and Wilkinson (1999), and the optimal number of loci following Kruskal (1964), using the Genes program.

The allele frequencies were obtained with the presence (1) and absence (0) of amplified loci in each ISSR primer for the $30 \quad P$. moniliformis individuals. The genetic diversity parameters were established using the Nei genetic distance estimation and the Shannon index, as calculated by the Popgene program, version 1.3. The genetic identity dendrogram was produced by the UPGMA grouping method (Unweighted Pair Group Method with Arithmetic Mean), using the NTSYS v.2.11 program. 


\section{RESULTS AND DISCUSSION}

Among the 28 primers tested, seven were selected (UBC 827, 840, 844, 857, 859, 860 and $873)$, which provided a total of 74 loci, ranging from 6 (UBC 844) to 14 loci (UBC 827), with an average of 11 loci per primer (Table 2). The tested ISSR molecular markers were efficient in DNA amplification and loci identification (Table 1). However, only those with the highest number of amplified loci and good fragment resolution were selected. The implemented markers are considered superior to other molecular techniques due to their low cost, high polymorphism rate and reproducibility, so they are fundamental for genetic studies aimed at the conservation and improvement of forest species (LORENZONI et al., 2014).

ISSR molecular markers were also efficient and suitable for genetic diversity studies of other forest species in semiarid regions of Northeast Brazil, which showed similarities in the mean number of loci found for $P$. moniliformis, such as $E$. velutina, in which the formation of 14 loci per primer was observed (GONÇALVES et al., 2014); M. caesalpiniifolia, in which the amplification of 78 loci was observed in seven primers and where the obtained average was 11 loci per primer (ARAÚJO et al., 2016); and M. urundeuva, in which selection seven primers were found, with the formation of 17 loci per primer (LOPES; COSTA; ARRIEL, 2020).

Table 2. Total number of loci, total number of polymorphic loci, polymorphism rate and Polymorphism Information Content (PIC), Marker Index (MI), and Resolving Power (RP) in each of the seven ISSR primers for 30 P. moniliformis individuals.

\begin{tabular}{|c|c|c|c|c|c|c|}
\hline ISSR Primer & $\begin{array}{l}\text { Total number of } \\
\text { loci }\end{array}$ & $\begin{array}{l}\text { Total number of } \\
\text { polymorphic loci }\end{array}$ & $\begin{array}{c}\text { Polymorphism rate } \\
(\%)\end{array}$ & PIC value & MI & $\mathrm{RP}$ \\
\hline UBC 827 & 14 & 13 & 92.9 & 0.375 & 4.875 & 10.50 \\
\hline UBC 840 & 12 & 9 & 75.0 & 0.299 & 2.691 & 4.57 \\
\hline UBC 844 & 6 & 6 & 100.0 & 0.364 & 2.184 & 8.60 \\
\hline UBC 857 & 12 & 11 & 91.7 & 0.384 & 4.224 & 7.40 \\
\hline UBC 859 & 11 & 10 & 90.9 & 0.423 & 4.230 & 7.57 \\
\hline UBC 860 & 9 & 6 & 66.7 & 0.268 & 1.608 & 8.20 \\
\hline UBC 873 & 10 & 6 & 60.0 & 0.295 & 1.770 & 9.80 \\
\hline Average & 11 & 9 & 82.4 & 0.344 & 3.08 & 8.09 \\
\hline Total & 74 & 61 & - & - & - & - \\
\hline
\end{tabular}

The total number of polymorphic loci found was 61 , with a mean of 9 polymorphic loci per ISSR primer, corresponding to $82 \%$ polymorphism and ranging from $60 \%$ (UBC 873 ) to $100 \%$ (UBC 844) (Table 2). A high polymorphism rate, of more than $53 \%$, was also observed for other forest species when ISSR molecular primers were used (GONÇALVES et al., 2014; BALLESTA et al., 2015; ARAÚJO et al., 2016; LOPES; COSTA; ARRIEL, 2020).

The MI ranged from 1.608 (UBC 860) to 4.875 (UBC 827), with the highest values for the UBC 827,857 and 859 primers, whereas RP of the loci varied from 4.57 (UBC 840) to 10.50 (UBC 827) (Table 2). These parameters provide important information to evaluate and assist in comparing ISSR primers (ROSA et al., 2017) and, in this context, the higher these parameters are, the more suitable the primers are for use in genetic diversity studies. PIC values ranged from 0.268 (UBC 860) to 0.423 (UBC 859 ), with a mean of 0.344 for the seven ISSR primers, which was considered moderately informative (Table 2). Values between 0.25 and 0.50 are considered moderately informative, whereas values higher than 0.50 are considered to be very informative, while those less than 0.25 are not very informative (BOTSTEIN et al., 1980). Similar results were found in $M$. caesalpiniifolia (0.397) occurring in the brazilian semiarid region (ARAÚJO et al., 2016).

Stress values below 0.05 indicate high precision in the estimates, and $r$ values close to 1.0 suggest a high correlation between the original genetic distance matrix and the simulated genetic distance matrix (KRUSKAL, 1964). Thus, it was possible to estimate enough loci for genetic diversity studies in P. moniliformis, as we found an increase in Pearson correlation values and a reduction of Kruskal stress values (Figure 2). When performing resampling with 53 loci, we obtained 0.045 for stress and 0.935 for correlation and these results confirm that the number of loci obtained in this study ( 74 loci) was sufficient to estimate the genetic diversity of $P$. moniliformis. 


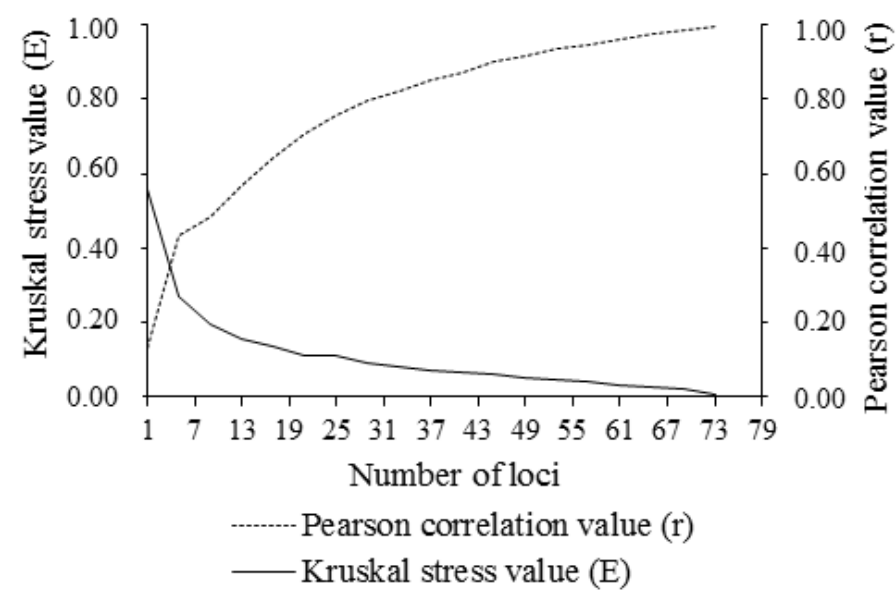

Figure 2. Pearson (r) correlation and Kruskal's stress (E) values as a function of the number of ISSR loci used to estimate the genetic diversity of 30 P. moniliformis individuals.

The Nei genetic diversity value for the study population was $\mathrm{He}=0.244 \pm 0.033$, while the Shannon index was $I=0.374 \pm 0.046$. These values are considered low since they can vary from 0 to 1 , with 1 being the maximum genetic diversity which may occur in a population; however, these results are similar to those obtained by Nybom (2004) in studying different molecular markers (RAPD, AFLP and ISSR) to estimate genetic diversity in wild plants (long-lived perennial and outcrossing species). The index is close to that found (using ISSR molecular markers) for populations of other widely-explored species of the semiarid region: C. prunifera $(\mathrm{He}=$ 0.327 and $I=0.470$ ) (FAJARDO et al., 2018), $H$. speciosa ( $H e=0.180$ and $I=0.260)$ (COSTA et al., $2015)$ and $M$. urundeuva $(H e=0.270$ and $I=0.420$ ) (LOPES; COSTA; ARRIEL, 2020).
Studies of the genetic diversity of trees, either within or between populations, are essential to the establishment of forest breeding programs, in order to capture maximum genetic variability (BALLESTA et al., 2015), for example, the development of active germplasm banks with several genotypes (NING et al., 2017).

From the Nei genetic identity grouping, it may be observed that there is high similarity (values between 0.65 and 0.98 ) among the P. moniliformis individuals of the study population. Six groups were formed at the cut-off point at 0.76 (Figure 3), in which Group 1 has 12 individuals, Group 2 consists of six individuals, Group 3 has eight individuals and Group 4 has two, while individuals 11 and 5 have each been designated as separate groups because they are genetically more distant from the other trees.

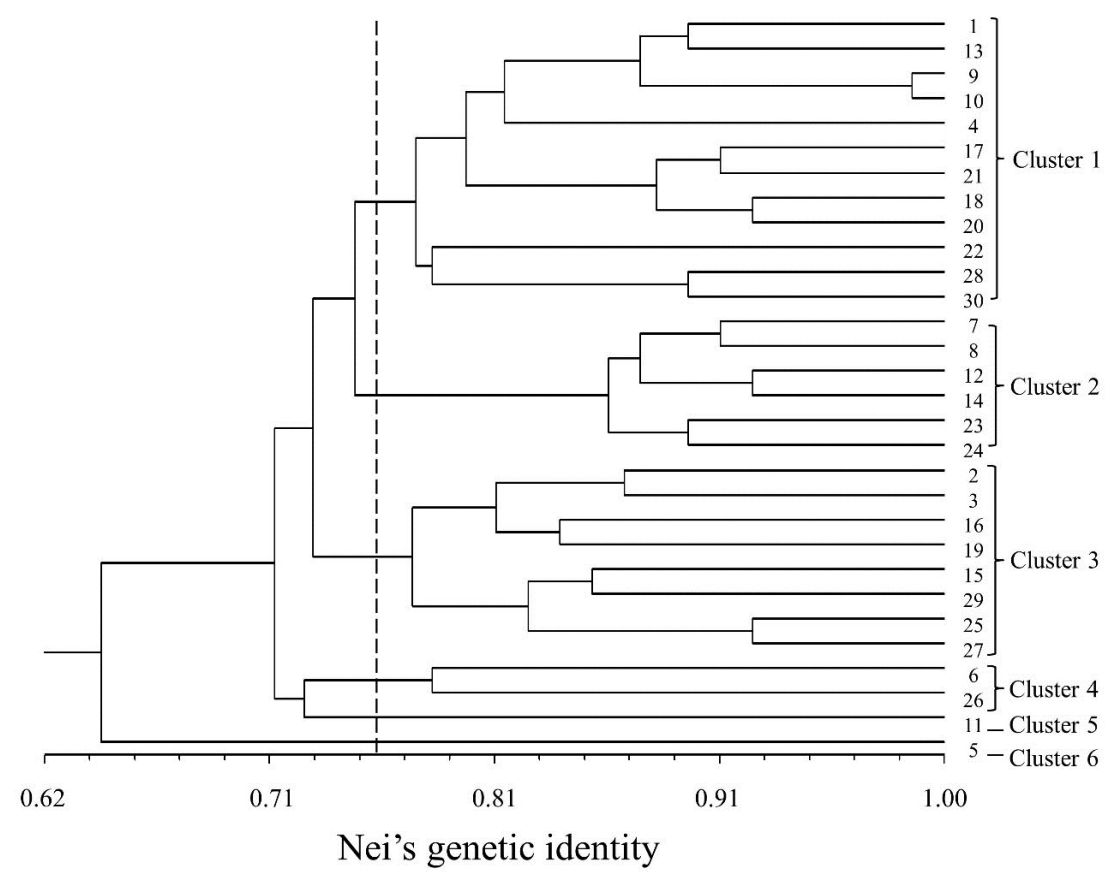

Figure 3. Nei genetic identity among 30 P. moniliformis individuals (cut-off point at 0.76 ) in a population at the Unidade Acadêmica Especializada em Ciências Agrárias, Macaíba City/Rio Grande do Norte State, Brazil. 
The studied population presents a discontinuity of $P$. moniliformis individuals, a species that naturally tends to occur in clusters. A more significant presence of these individuals was also observed at the edges of the population fragments, which is an indication that the anthropization in the region where the Forest Experimentation Area is located (Macaíba/Rio Grande do Norte State, Brazil) has caused the current discontinuity. Another point to be considered is that there are individuals that are genetically close (Group 1) spread across the entire population (Figure $1)$.

The selection of groups of parent trees with higher genetic divergence is a strategy to increase the variability of the species that has several potential uses. This selection aims to capture greater genetic diversity in the collection of seeds to produce seedlings used in the recovery of degraded areas, germplasm banks and the selection of matrices for the formation of seed orchards. Adding seed sources from other populations in the semiarid region of the northeast of Brazil is also an alternative which could be used to increase the genetic variability of the species.

\section{CONCLUSIONS}

The ISSR molecular markers (UBC 827, 840, $844,857,859,860$ and 873) are considered to be efficient in genetic diversity studies of populations, selection of matrices and germplasm banks, and may contribute to the conservation and genetic improvement of $P$. moniliformis populations.

\section{ACKNOWLEDGEMENTS}

This study was financed in part by the Coordenação de Aperfeiçoamento de Pessoal de Nível Superior - Brasil (CAPES) - Finance Code 001. The authors thank the Fundação de Apoio à Pesquisa do Rio Grande do Norte for the grant of scholarships. The access to genetic heritage of this research was registered in Sistema Nacional de Gestão do Patrimônio Genético e do Conhecimento Tradicional Associado (SisGen) and identified by the codes: A0C8FD7 and A5DB85E.

\section{REFERENCES}

ALVES, M. J. et al. Phenols, flavonoids and antioxidant and cytotoxic activity of leaves, fruits, peel of fruits and seeds of Piptadenia moniliformis Benth (Leguminosae - Mimosoideae). Boletín Latinoamericano $y$ del Caribe de Plantas Medicinales y Aromáticas, 13: 466-476, 2014.
ANDERSON, J. A. et al. Optimizing parental selection for genetic linkage maps. Genome, 36: 181 $-186,1993$.

ARAÚJO, F. S. et al. ISSR molecular markers for the study of the genetic diversity of Mimosa caesalpiniaefolia Benth. Idesia, 34: 47-52, 2016.

AZERÊDO, G. A.; PAULA, R. C.; VALERI, S. V. Determining the viability of Piptadenia moniliformis Benth seeds with the tetrazolium test. Journal of Seed Science, 33: 61-68, 2011.

BALLESTA, P. et al. Analysis of the genetic diversity of Eucalyptus cladocalyx (sugar gum) using ISSR markers. Acta Scientiarum Agronomy, 37: 133-140, 2015.

BOTSTEIN, D. et al. Construction of genetic linkage map in man using restriction fragment length polymorphisms. American Journal of Human Genetics, 32: 314-331, 1980.

CHAGAS, K. P. T. et al. Genetic diversity of longestablished populations of Elaeis guineensis Jacquin (Arecaceae). Revista Brasileira de Fruticultura, 41: e023, 2019.

CHEN, Y. et al. Genetic diversity and variation of Chinese fir from Fujian province and Taiwan, China, based on ISSR markers. Plos One, 12: 01-14, 2017.

COSTA, D. F. et al. Genetic diversity and selection of ISSR primers in a natural mangaba population (Hancornia speciosa Gomes) (Apocynaceae). Revista Brasileira de Fruticultura, 37: 970-976, 2015.

COSTA, J. C. et al. Genetic diversity in natural populations of Stylosanthes scabra using ISSR markers. Genetics and Molecular Research, 17: 18, 2018.

COSTA, T. S. et al. Genetic diversity of accessions of the mangaba germplasm bank in Sergipe, Brazil. Pesquisa Agropecuária Brasileira, 46: 499-508, 2011.

DOYLE, J. J.; DOYLE, J. L. Isolation of plant DNA from fresh tissue. Focus, 12: 13-15, 1987.

DUARTE, M. M.; NOGUEIRA, A. C.; VIEIRA, E. S. N. Diversity and spatial genetic structure of natural populations of Ziziphus joazeiro Mart. Brazilian Journal of Agricultural Sciences, 13: e5573, 2018.

FARIAS, D. F. et al. Water extracts of brazilian leguminous seeds as rich sources of larvicidal compounds against Aedes aegypti L. Anais da 
Academia Brasileira de Ciências, 82: 585-594, 2010 .

FAJARDO, C. G. et al. Genetic and phenotypic association of the carnauba palm tree evaluated by inter-simple sequence repeat and biometric traits. Genetics and Molecular Research, 17: 1-9, 2018.

GONÇALVES, L. O. et al. Caracterização genética de mulungu (Erythrina velutina Willd.) em áreas de baixa ocorrência. Revista de Ciência Agronômica, 45: 290-298, 2014.

GOOGLE EARTH PRO. Google Earth Pro para PC, Mac ou Linux. Disponível em: <https:// www.google.com.br/earth/download/gep/ agree.html>. Acesso em: 01 jul. 2018.

JESUS, M. C. et al. Study of pollen from light honeys produced in Piauí State, Brazil. Palynology, 39: 110-124, 2015.

$\mathrm{KOUR}$, B. et al. In vitro mass multiplication and assessment of genetic stability of in vitro raised Artemisia absinthium L. plants using ISSR and SSAP molecular markers, Advances in Botany, 2014: 01-07, 2014.

KRUSKAL, J. B. Multidimensional scaling by optimizing goodness of fit to a no metric hypothesis. Psychometrika, 29: 1-27, 1964.

LOPES, J. S.; COSTA, M. R. J.; ARRIEL, D. A. A. Genetic diversity of potential mother trees of Myracrodruon urundeuva Allemão in a remnant population from Brazilian Cerrado using ISSR. Advances in Forestry Science, 7: 1017-1024, 2020.

LORENZONI, R. M. et al. Using ISSR for finger printing accessions of biribazeiro. Revista Brasileira de Fruticultura, 36: 251-257, 2014

NASCIMENTO, M. F. et al. OSB panels made with wood species from the Brazilian Northeast's Caatinga. Ambiente Construído, 15: 41-48, 2015

NEVES, A. G. S. et al. Selection of ISSR molecular primers for genetic variability studies of Syagrus cearensis Noblick. Agropecuária Científica no Semiárido, 15: 228-231, 2019.

NING, Z. et al. Core germplasm construction of Cornus officinalis by ISSR markers. Journal of Agricultural Biotechnology, 2: 579-587, 2017.

NYBOM, H. Comparison of different nuclear DNA markers for estimating intraspecific genetic diversity in plants. Molecular Ecology, 13: 1143-1155, 2004.
PREVOST, A.; WILKINSON, M. J. A new system of comparing PCR primers applied to ISSR fingerprinting of potato cultivars. Theoretical and Applied Genetics, 98: 107-112, 1999.

ROSA, J. D. et al. Variability and population genetic structure in Achyrocline flaccida (Weinm.) DC., a species with high value in folk medicine in South America. Plos One, 12: e0183533, 2017.

SILVA, T. S. S. et al. Caracterização e seleção de marcadores moleculares em Croton linearifolius Mull. Arg. como subsídio para estudos genéticos. Multi-Science Journal, 1: 04-08, 2018.

SIMON, M. F. Manual de curadores de germoplasma - vegetal: conservação in situ. Brasília: Embrapa Recursos Genéticos e Biotecnologia, Colombo, 322: 1-14, 2010.

VARSHNEY, R. K. et al. Comparative assessment of ESTSSR, EST-SNP and AFLP markers for evaluation of genetic diversity and conservation of genetic resources using wild, cultivated and elite barleys. Plant Science, 173: 628-649, 2007. 